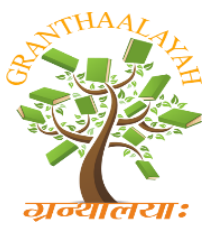

\author{
INTERNATIONAL JOURNAL OF RESEARCH - \\ GRANTHAALAYAH \\ A knowledge Repository
}

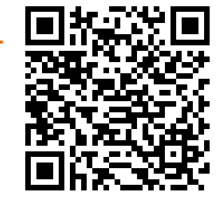

\title{
DEFORESTATION- A SOCIO-LEGAL PERSPECTIVE
}

\author{
Manleen Kaur
}

Ph.D. Student, Dept. of Laws, Panjab University, Chandigarh

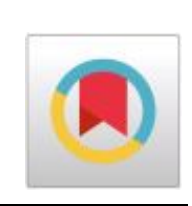

\section{ABSTRACT}

Forests are not only mere providers of forest products but also offer various services like providing a mechanism of carbon sequestration and evading big disasters by preventing soil erosion, floods, landslides apart from being home to humans as well as diverse species. Recently there has been growing awareness and realization with regard to the role that forests play- as drivers of national growth. With growing population, needs and knowledge, the responsibility of forest sector is now not only limited to meeting the environmental concerns but encompasses livelihood issues which in turn will affect the economic and social needs of the country.

Keywords:

Deforestation, growing population, national growth, Legal Perspective.

\section{INTRODUCTION}

Amongst poorest nations, forests contribute to $10 \%$ of the GDP by providing formal employment as well as informal employment but still progress towards sustainable forest management is limited, and there is continuing loss and degradation of forests in many developing countries. "Losing forest diversity means missing opportunities for medicines, food, raw materials and employment opportunities, in one word: welfare"-FAO.

Since times immemorial, Indian society has been aware and conscious of the necessity of protecting the environment and ecology. But during the colonial period forests became the victims of the growing demands of industrialization and capitalism which led to unprecedented cutting of trees. Moreover the laws facilitated the state to claim the forest land and regulate the supply of timber with the motive of full-fledged exploitation of forest resources. This led to forest degradation and in turn destruction of wildlife habitat thereby wrongfully making the rightful inhabitants, encroachers.

After independence, efforts towards applied forestry research have gained a momentum and various policies have been framed. For instance, the Forest Policy of 1952 recognized the multithronged contribution of forests although its focus remained on the sustenance of timber production. Another major policy namely, the Forest Policy of 1988 made a significant departure from the earlier policies and gave primacy to the conservation of forests. The underlying objective of the policy was to ensure environmental stability and ecological balance by expanding the forest and tree cover of India to 33 percent of the total area of the country. Now derivation of economic benefit became a subordinate goal. This led to a less preferential attitude towards forest based industries which earlier got concessional supply of raw material from forests. The Ministry of Environment, Forest \& Climate Change (MoEFCC) has been taking various initiatives like the National Afforestation Policy, 1992, to promote afforestation, tree planting, ecological restoration 
and eco development activities; Joint Forest Management Program, 1990, based on the 'principle of care and share to promote participation at grass root level; National Forestry Action Programme, 1999, reiterating the objectives of the NFP 1988; The National Working Plan Code, 2004, talked about the integration of traditional forestry with the new objectives of Sustainable Forest Management.

Apart from the aforesaid efforts, all the Five Year Plans (FYP) till date have always mentioned concern for the increase in the productivity of forests, to link up forest development with various forest-based industries and to develop forests as a support to rural economy. Afforestation has been encouraged and concern over the increasing urbanization has been brought to light.

Regarding the legislative framework, the issue of environmental protection was initially dealt indirectly as part of protecting the public health and as part of other legislation like the Indian Penal Code. But with the international developments taking place, apart from the generic concern, evident under Article 48A and Article $51 \mathrm{~A}(\mathrm{~g})$, of the Constitution of India, 'Forests' is dealt with, in the concurrent list of the Seventh Schedule under entry 17-A. There are various legislations also like The Indian Forest Act, 1927 which was enacted to regulate transit of forest produce and to levy duty on timber and other forest produce. Under this Act, the state government was given blatant powers to declare any forest as reserved not considering the rights of forest dwellers and to achieve the basic purpose of earning revenue. Then ushered in The Forest (Conservation) Act, 1980 and The Forest (Conservation) Rules, 2003, which made the prior approval of the Central Government necessary, for de-reservation of reserved forests and for the use of forest land for nonforest purposes.

In ultimate analysis, economic development at the cost of deforestation would not be long lasting. Therefore, there is an absolute need to take all precautionary measures when forest lands are sought to be directed for non- forest use. As non-obstante clause, Section 2 of the 1980 Act made the prior approval of the Central Government a condition precedent even in cases of renewal of existing lease so that incidents of diversion of forest land for non-forest purposes decrease.

The Supreme Court in the case of Rural Litigation and Entitlement Kendra, Dehradun v. state of UP re-emphasized that whether it is case of first grant or renewal following exercise of option by lease, the compliance of section 2 of the Act is a condition precedent. This observation has been quoted by courts in various cases like in M C Mehta wherein it was held by the Apex Court that no mining operation can commence without obtaining environmental impact assessment and prior permission of the Government.

So a trend is seen that for the purpose of monetary gains if the industrial units are trying to manipulate the law, it is being checked by judiciary.

In the T.N.Godavarman case, the concept of 'Net Present Value' in context of forestry has been discussed. It was said that forestry is a public project and the benefit received today is in fact 'cost incurred' today. It has long gestation period of 40-50 years undergoing cost cycles each year depending upon inflation, rate of interest, internal rate of return etc. Environmental outputs from forests appear as public goods for which there is no market like: Flood Control Benefits; Water Production; Soil Conservation; Outdoor Recreation; Biodiversity \& Conservation; Habitat; Air Purification. The problem in valuation of the above outputs is: allocation of fixed costs according to the contribution of each product in total revenue.

It can be witnessed by the judgment in the aforesaid case, that how important and valuable the forests are, though the returns come slowly, it has to be understood that their contribution to the survival of mankind is immense and highly significant. 
But still deforestation in the name of mining, developmental projects, industry is rampant. According to a report (Down to Earth) in the MoEFCC has been giving clearances for forest diversion to developmental projects at an unprecedented rate and also of the total forest area diverted, maximum has been done for mining and irrigation projects and rest for road construction, drinking water schemes and hydropower projects. For instance, Maharashtra's Raigarh forest has been diverted for drinking water supply project on Kalu River, wherein it has been alleged that the Environment Impact Assessment was not done and the Central Advisory Committee changed its observations, indicating some other reality.

Another issue which is of significant concern is the social and livelihood issues related to deforestation apart from the environmental depletion. There is a lot of hue and cry over the rehabilitation of the displaced and how they have to be compensated.

In another latest report allegations have been levied against Singareni Collieries Company Limited (SCCL), a coal mining company based in Godavari valley, Andhra Pradesh, for causing multiple displacements of the Konda Reddis and Koya tribes residing in the affected villages. These forest dwellers and tribesmen have been evicted from their own land and the company has acquired their land without their consent leading to livelihood issues. They allege gross violation of the Scheduled Tribes and Other Forest Dwellers' Protection of Rights Act, 2006 as the consent of gram sabha which is mandatory before the grant of forest clearance has not been taken.

As gathered from the aforesaid discussion, deforestation is not only limited to the ecological loss but starts a vicious cycle of erosion of life resources which in turn affect the flora and fauna thereby affecting the human life and leaving the inhabitants in poverty and despair. To curb the menace of deforestation various tools have been put in place like sustainable forest management, National Forest Information system and forest certification. Various regional consultations and surveys are also being carried out for this purpose. But it calls for an urgent need to put in right efforts in right direction with right intention.

\section{REFERENCES}

1. http://www.fao.org/biodiversity/components/forests/en/

2. J.V Sharma, Priyanka Kohli, Forest governance and implementation of REDD+ in India, Ministry of Environment and Forests.

3. Jagdish Kishwan, Devendra Pandey, et.al. (eds.), India's Forests. MoEF, Government of India Publication, New Delhi (2007)

4. M C Mehta v. Union of India, (2004) 12 SCC 118.

5. Planning Commission Reports.

6. Ramanathan, Soundaram, Mining Sans Social Consent,Down To Earth (September 2013).

7. Rural Litigation and Entitlement Kendra, Dehradun v. state of UP 1989 Supp (1) SCC 504

8. Smriti Das, The Strange Valuation of Forests in India, EPW (February 2010).

9. Srestha Banerjee, "Clearance Rush” Down To Earth (July1-15,2013)

10. T.N. Godavarman Thirumulpad v. Union of India (UOI) and Ors., (2006) 1 SCC 1. 